\title{
Ozonation of Direct Red-23 dye in a fixed bed batch bubble column reactor
}

\author{
Sukanchan Palit \\ 43,Judges Bagan,P.O.-Haridevpur,Kolkata-700082,India. \\ Queen's Univ., School of Planning, Architect. \& Civil Engg., David Keir Building, Stranmillis Rd., Belfast BT9 5AG, U.K. \\ sukanchan68@gmail.com; spalit01@qub.ac.uk
}

\begin{abstract}
This study reports the decolourization of direct Red-23 dye by ozonation in a fixed bed batch bubble column reactor. The conversion percentage for bubble column with media is reported high. This research enhances our concept that fixed bed batch bubble column reactor is effective in degradation of dyes. The large utilization of synthetic dyes is a matter of environmental concern since some of them are potentially toxic, mutagenic and carcinogenic.
\end{abstract}

Keywords: Dyes, Red-23, ozone, bubble column, degradation, textile effluent.

\section{Introduction}

Textile industry generates highly polluting waste water. Various textile chemicals such as wetting agents, dyes, surfactants, fixing agents, softeners, and many other additives are used in wet processes such as bleaching, dyeing and finishing processes. Strong colour of the textile wastewater is the most serious problem of the textile waste effluent. Textile dyeing effluents are known to present extreme variations of $\mathrm{pH}$, high temperature, high COD and high concentration of dissolved salts. Treatment of wastewater containing reactive dyes is a severe problem for the cotton textile industry. Ozonation is perhaps the most advanced method ever attempted for decolorization of the textile effluents.

The oxidation potential of ozone $(2.07 \mathrm{~V})$ is 1.52 times higher than that of chlorine which allows degrading most organic compounds. The oxidizing ability of ozone is derived from the third, or nascent, oxygen atom. Ozone and hydroxyl radicals $\left(\mathrm{OH}^{-1}\right)$ generated in the aqueous solution are able to open the aromatic rings. The use of ozone in textile effluent treatment appears as a very attractive alternative within considerable application potential. Ozone is a powerful oxidising agent $\left(E^{0}=2.08 \mathrm{~V}\right)$ and can react with several classes of compounds through direct or indirect reaction.

The chromophore groups generally are organic compounds with conjugated double bonds that can be broken by ozone (directly or indirectly) forming smaller molecules, which decrease the effluent colour. Table 1 provides the composite

Table 1. Composite textile industry wastewater characteristics

\begin{tabular}{|l|l|}
\hline \multicolumn{1}{|c|}{ Parameters } & \multicolumn{1}{c|}{ Values } \\
\hline $\mathrm{pH}$ & $7.0-9.0$ \\
\hline Biochemical oxygen demand(mg/L) & $80-6000$ \\
\hline Chemical oxygen demand(mg/L) & $150-12000$ \\
\hline Total suspended solids(mg/L) & $15-8000$ \\
\hline Total dissolved solids(mg/L) & $2900-3100$ \\
\hline Chloride(mg/L) & $1000-1600$ \\
\hline Total Kjeldahl nitrogen(mg/L) & $70-80$ \\
\hline
\end{tabular}<smiles>CC(=O)Nc1ccc(N=Nc2c(S(=O)(=O)O[Na])cc3cc(NC(=O)Nc4ccc5c(O)c(N=Nc6ccccc6)c(S(=O)(=O)O)cc5c4)ccc3c2O)cc1</smiles>

Fig. 1. Structure of Direct Red 23 dye

"Decolourization of textile dye (Red-23) by ozonation" http://www.indjst.org textile industry wastewater characteristics.

\section{Methods and literature survey}

Konsowa et al. (2003) investigated the decolorization of wastewater containing direct dye by ozonation in a batch bubble column reactor. Their experimental set up included an air dryer, compressor, ozone generator, glass bubble column reactor and four washing bottles. The air dryer consisted of a column which was filled with a high adsorptive molecular sieve. Ozone was generated using laboratory ozonizer Model 301-7 (Erwin Sander); water we cooling medium. The reactor has a glass column of $5 \mathrm{~cm}$ diameter and $35 \mathrm{~cm}$ height with sintered glass at the bottom through which $\mathrm{O}_{3}$ was introduced to the solution. The reactor was followed by four washing them containing $250 \mathrm{ml}$ of acidified $2 \% \mathrm{KI}$ solution for determining unreacted ozone. Before each run, the bubble column reactor was filled with $500 \mathrm{~cm}^{3}$ of the dye solution. Compressed dry air was allowed to pass through the ozonizer where ozone formation takes place. The outlet stream from the ozonizer containing $\mathrm{O}_{3}, \mathrm{O}_{2}$ and a $\mathrm{N}_{2}$ mixture was allowed to pass through tygon tubing connected to the bottom of the bubble column. The gas flow rate was controlled by a needle valve and was measured by air flowmeters. The temperature was fixed at $20^{\circ} \mathrm{C}$ during all the experiments. The dye concentration time data during decolorization was detected using spectrophotometry.

The unreacted ozone was taken out of the bubble column reactor through the tygon tubing and bubbled into the $25 \mathrm{KI}$ solution contained in the washing bottles where the potassium iodide reacted with the excess ozone according to the following equation:

$\mathrm{O}_{3}+\mathrm{KI}+\mathrm{H}_{2} \mathrm{O}------\mathrm{I}_{2}+2 \mathrm{KOH}+\mathrm{O}_{2}$

The resulting iodide was titrated using standard sodium thiosulphate in the presence of starch as the indicator. The values of unreacted and reacted ozone were determined accordingly.

Another landmark work was done by Turhan et al. (2009) in the area of decolorization of direct dye in textile waste water by ozonization in a semi-batch bubble column reactor. They have taken direct dye (Sirius Blue SBRR) and the

Sukanchan Palit Indian J.Sci.Technol. 
experimental methodology applied by these researchers is as follows:

Ozone was generated from oxygen $(99.9 \%$ purity) by a labscale ozone generator, Fischer 502 Model. The reactor had a glass column of $5 \mathrm{~cm}$ in diameter and $110 \mathrm{~cm}$ height with sintered

Fig.2. Dye concentration vs time without media
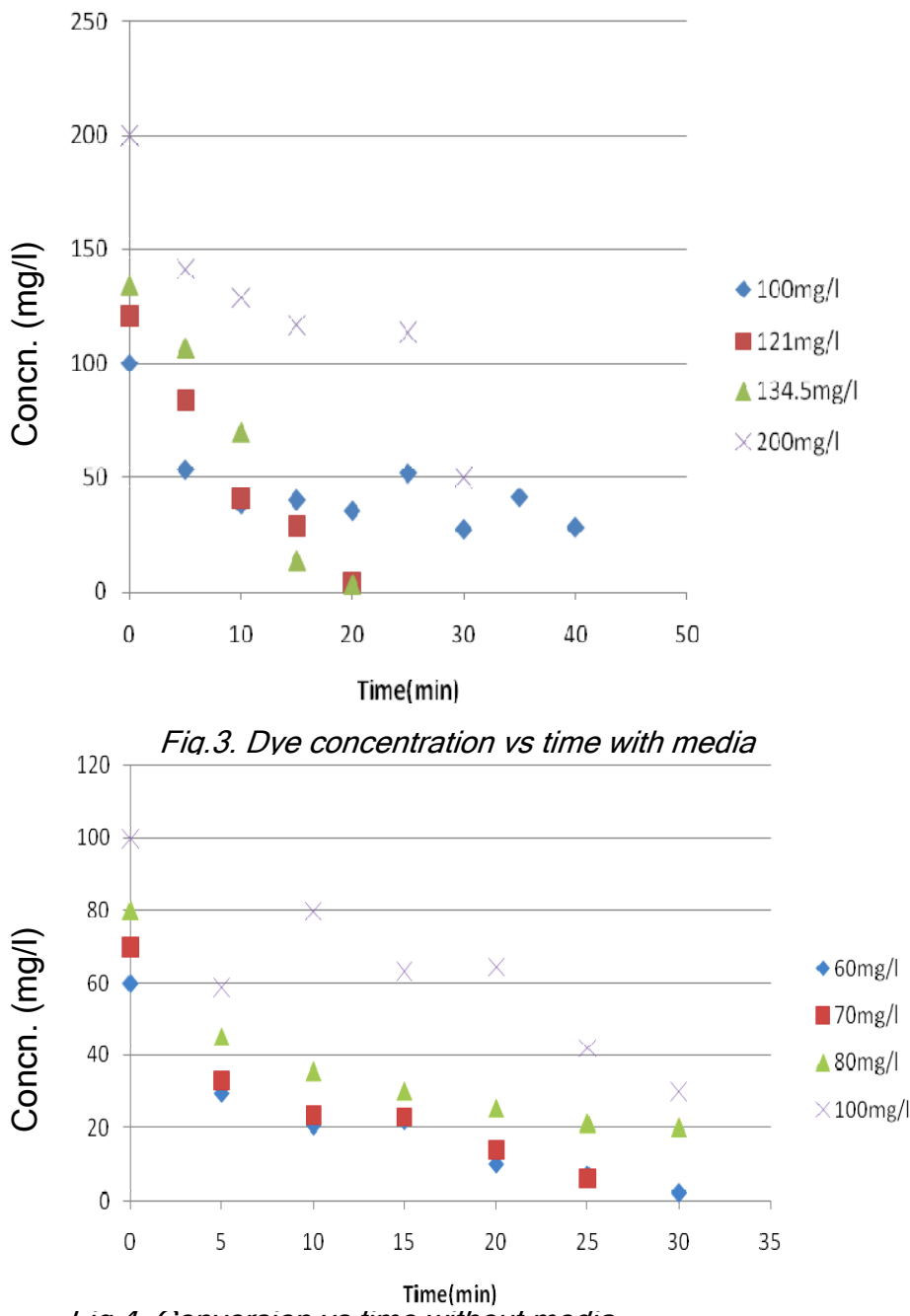

rIg.4. Conversıon vs time without media

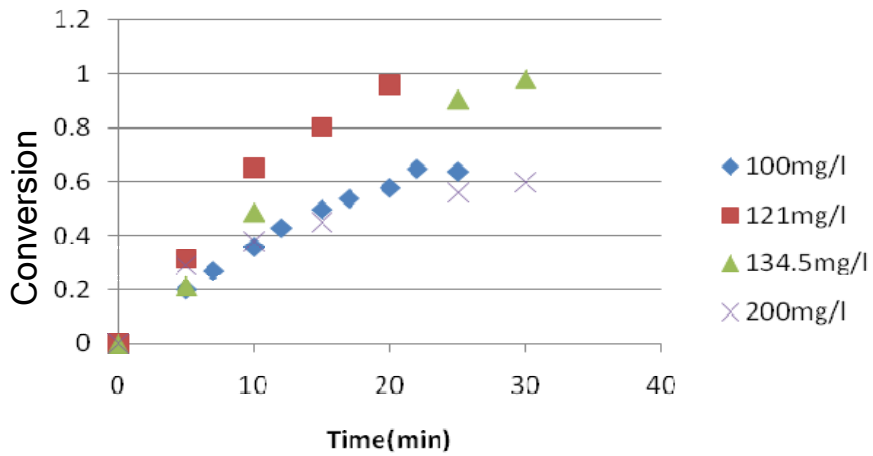

Research article

(C)Indian Society for Education and Environment (iSee)
Table 2. provides the final degradation (with gravels)-a fixed bed system

\begin{tabular}{|l|l|l|}
\hline $\begin{array}{c}\text { Initial dye } \\
\text { concentration (mg/l) }\end{array}$ & $\begin{array}{c}\text { De-colorization } \\
(\%)-D\end{array}$ & $\begin{array}{c}\text { Time } \\
(\mathrm{min})\end{array}$ \\
\hline 60 & 96 & 30 \\
\hline 70 & 91 & 25 \\
\hline 80 & 75 & 30 \\
\hline 100 & 70 & 30 \\
\hline
\end{tabular}
connected to the bottom of the bubble column. The gas flow rate was controlled by a needle valve and measured by air flow meters. The temperature was fixed at $20+(-) 1^{0} \mathrm{C}$ during all the experiments. The $\mathrm{pH}$ of wastewater was adjusted to the desired level with Merck quality analytical grade $0.1 \mathrm{~N} \mathrm{NaOH}$ and $\mathrm{H}_{2} \mathrm{SO}_{4}$. The unused ozone was analysed in the same procedure as Konsowa et al. (2003). The concentrations of dye solutions were determined by Agilent 8453 model spectrophotometer at its maximum absorption wavelength of $594 \mathrm{~nm}$ for Sirius Blue SBRR. The dye concentration time data during decolorization were analysed spectrophotometrically.

The present study is attempted to investigate the reaction (conversion) or decolorization efficiency of ozonation of Direct Red 23 dye (commonly used in textile industries) (Fig.1) at different concentrations by employing simple bubble column and a fixed bed bubble column. Initial dye concentrations of $100 \mathrm{mg} / \mathrm{l}$, $121 \mathrm{mg} / \mathrm{l}, 134.5 \mathrm{mg} /, 200 \mathrm{mg} / \mathrm{l}$ are taken out for measuring the absorbance (or concentrations) at different time intervals of $5,10,15,20,25,30$ and 35 minutes. The ozonation is done in an Ozonizer (ENALY-CHINA make) whose output is $200-300 \mathrm{mg} / \mathrm{hr}$. Also experiments are done with initial concentrations of $60 \mathrm{mg} / \mathrm{l}, 70 \mathrm{mg} / \mathrm{l}, 80 \mathrm{mg} / \mathrm{l}$ and $100 \mathrm{mg} / \mathrm{l}$ with gravels like fixed bed. Absorbances are measured with the help of UV spectrophotometer (UNICAM).

The relation between absorbance and concentration is $y=0.0302 x+0.4135$

[y=Absorbance, $\mathrm{x}=$ concentration $(\mathrm{mg} / \mathrm{l})$ ]

$\mathrm{R}^{2}=0.9655, \mathrm{R}=$ Regression coefficient.

Then we investigated ozonation kinetics of Direct Red 23. The conversion/ decolorization efficiency is found out by $\mathrm{D}=\left[\left(\mathrm{C}_{\mathrm{A} 0}-\mathrm{C}_{\mathrm{A}}\right) / \mathrm{C}_{\mathrm{A} 0}\right] 100$

$\left[\mathrm{C}_{\mathrm{A} 0}=\right.$ Initial dye concentration in $\mathrm{mg} / \mathrm{l}, \mathrm{C}_{\mathrm{A}}=$ Dye concentration at any time $\mathrm{t}$ in $\mathrm{mg} / \mathrm{l}]$

\section{Results and discussion}

a) About $80 \%$ degradation obtained for $60 \mathrm{mg} /$ I,70mg/l,80mg/l and $100 \mathrm{mg} / \mathrm{l}$ of dye in presence of gravels.

b) Within 30 minutes of the initiation of ozonation, the degradation reaches $80 \%$ for all concentrations studied.

c) Table 2 provides the final degradation (with gravels)a fixed bed system. Fig.2-6 reflects various factors considered in the study on the degradation of Red-23 dye. 
d) Some other trends (without media or gravels) are provided in Table 3.

The degradation rate is higher for bubble column reactor with gravels or media. It shows that the fixed bed bubble column reactor is effective. High mass transfer rate and high contact surface area are the probable helpful factors in dye degradation.

Fig.5. Conversion vs time with media

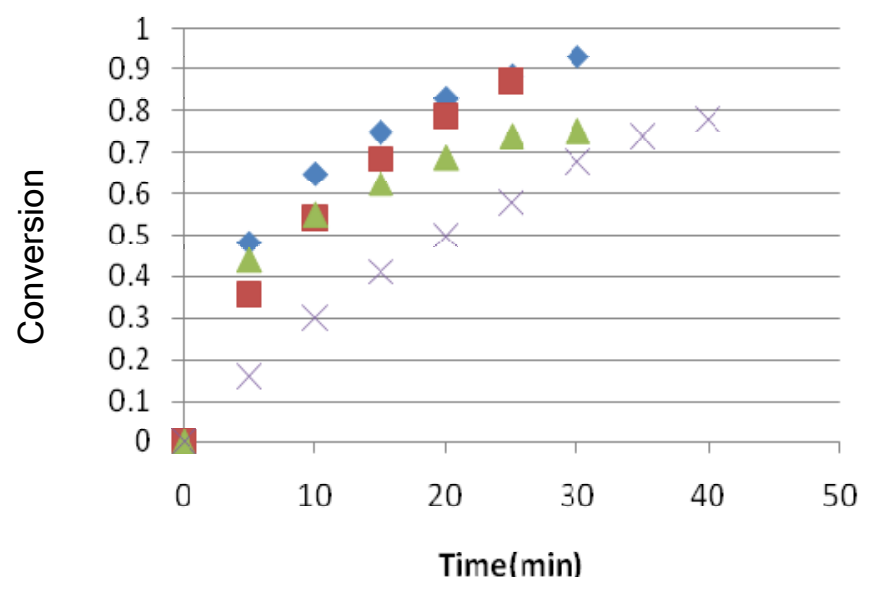

\section{Conclusion}

Dye ozonation can be a promising approach in textile-dye effluent treatment as approach is environmentally friendly, and produces non-hazardous products. Dye ozonation in a fixed bed batch bubble column reactor is a new and innovative approach.

Presence of media enhances the reaction. Our research validates this concept.

Table 3. Final degradation without media or gravel

\begin{tabular}{|l|l|l|}
\hline $\begin{array}{c}\text { Initial dye concen. } \\
(\mathrm{mg} / \mathrm{l})\end{array}$ & $\begin{array}{c}\text { De-colorization } \\
(\%)-\mathrm{D}\end{array}$ & Time(min) \\
\hline 100 & 72 & 40 \\
\hline 121 & 97 & 20 \\
\hline 134.5 & 98 & 30 \\
\hline 200 & 75 & 30 \\
\hline
\end{tabular}

\section{References}

1. Koch M, Yediler A, Lienert D, Insel G, Kettrup A (2002) Ozonation of hydrolysed azo dye reactive yellow 84(Cl), Chemosphere. 46, 109-113.

2. Konsowa AH (2003) Decolorization of wastewater containing direct dye by ozonation in a batch bubble column reactor. Desalination. 158, 233

3. Muthukumar M, Selvakumar N (2004) Studies on the effect of inorganic salts on decolouration of acid dye effluents by ozonation. Dyes \& Pigments. 62, 221228.

4. Silva AC, Pic JS, Sant'Anna Jr. GL and Dezotti M (2009) Ozonation of azo dyes(Orange II and Acid Red 27) in saline media. J. Hazardous Materials. 169, 965971.
Vol.2 No.10 (Oct 2009)

ISSN: 0974- 6846

5. Turhan K and Turgut Z (2009) Decolorization of direct dye in textile wastewater by ozonization in a semi-batch bubble column reactor. Desalination. 242,256-263.

6. Wang C, Yediler A, Lienert D, Wang Z, Kettrup A (2003) Ozonation of an azo dye C.I. Remazol Black 5 and toxicological assessment of its oxidation products. Chemosphere. 52,1225-1232.

Fig.6. Structure of a bubble column reactor

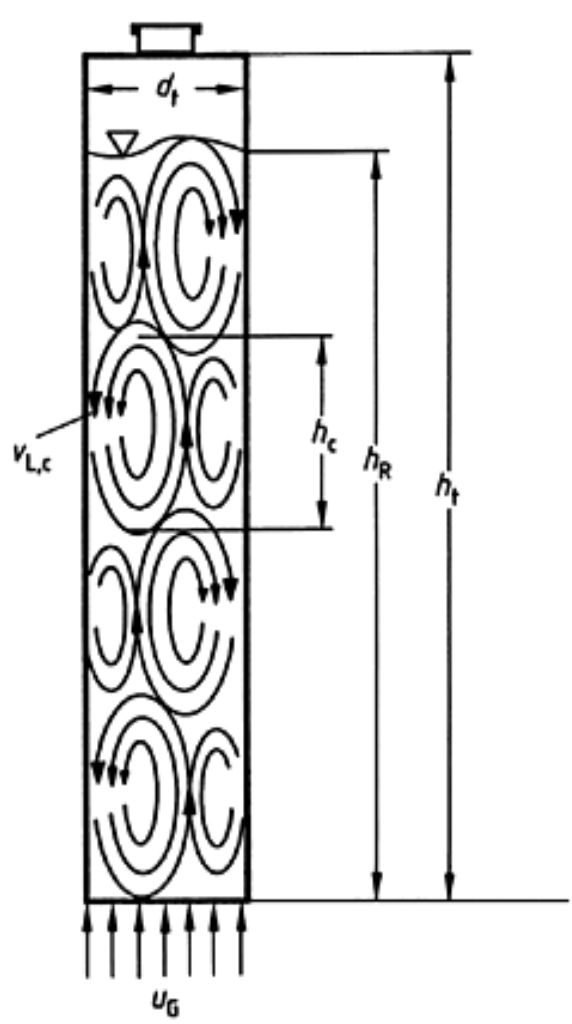

